\title{
UV/chlorine treatment of carbamazepine: Transformation products and their formation kinetics
}

Yanheng Pan ${ }^{1}$, ShuangShuang Cheng ${ }^{1}$, Xin Yang ${ }^{1 *}$, Jingyue Ren ${ }^{1}$, Jingyun Fang ${ }^{1}$,

Chii Shang ${ }^{2}$, Weihua Song ${ }^{3}$, Lushi Lian ${ }^{3}$ and Xinran Zhang ${ }^{1}$

${ }^{1}$ School of Environmental Science and Engineering, Sun Yat-sen University, Guangzhou 510275, China

${ }^{2}$ Department of Civil and Environmental Engineering, the Hong Kong University of Science and Technology, Clear Water Bay, Kowloon, Hong Kong

${ }^{3}$ Department of Environmental Science \& Engineering, Fudan University, Shanghai 200433, China

*Corresponding author: yangx36@mail.sysu.edu.cn (X. Yang)

Submitted to Water Research 
Abstract: Carbamazepine (CBZ) is one of the pharmaceuticals most frequently detected in the aqueous environment. This study investigated the transformation products when CBZ is degraded by chlorine under ultraviolet (UV) irradiation (the UV/chlorine process). Detailed pathways for the degradation of CBZ were elucidated using ultra-high performance liquid chromatography (UHPLC)-quadrupole time-of-flight mass spectrometry (QTOF-MS). CBZ is readily degraded by hydroxyl radicals $\left(\mathrm{HO}^{\circ}\right)$ and chlorine radicals $\left(\mathrm{Cl}^{\circ}\right)$ in the UV/chlorine process, and 24 transformation products were identified. The products indicate that the 10,11-double bond and aromatic ring in CBZ are the sites most susceptible to attack by $\mathrm{HO}^{\circ}$ and $\mathrm{Cl}^{\circ}$. Subsequent reaction produces hydroxylated and chlorinated aromatic ring products. Four specific products were quantified and their evolution was related with the chlorine dose, $\mathrm{pH}$, and natural organic matter concentration. Their yields showed an increase followed by a decreasing trend with prolonged reaction time. CBZ-10,11-epoxide (I), the main quantified transformation product from $\mathrm{HO}^{\circ}$ oxidation, was observed with a peak transformation yield of 3-32\% depending on the conditions. The more toxic acridine (IV) was formed involving both $\mathrm{HO}^{\circ}$ and $\mathrm{Cl}^{\bullet}$ with peak transformation yields of $0.4-1 \%$. All four quantified products together amounted to a peak transformation yield of $34.5 \%$. The potential toxicity of the transformation products was assayed by evaluating their inhibition of the bioluminescence of the bacterium Vibrio Fischeri. The inhibition increased at first and the decreased at longer reaction times, which was in parallel with the evolution of transformation products.

Keywords: carbamazepine; UV/chlorine; transformation products; kinetics 


\section{Introduction}

Micropollutants such as pharmaceuticals are of great concern because of their potential impact on aquatic environments. Carbamazepine (CBZ) is one of the pharmaceuticals most frequently detected in aqueous environments, including surface water, groundwater and wastewater effluents (Huerta-Fontela et al., 2011; Jelic et al., 2011; Kolpin et al., 2002; Mohapatra et al., 2014; Miao and Metcalfe, 2003). CBZ is one of the most persistent pharmaceuticals in water bodies and is resistant to photodegradation and microbial degradation in the environment (Andreozzi et al., 2002; Kosjek et al., 2009). CBZ is difficult to remove by conventional wastewater treatment processes such as coagulation/flocculation and chlorination (Snyder et al., 2007). Advanced oxidation processes (AOPs), especially ultraviolet-based AOPs, have proven effective in degrading many organic contaminants by taking advantage of highly reactive hydroxyl radical $\left(\mathrm{HO}^{\circ}\right)$. A variety of AOPs have been evaluated for removing trace organic contaminants in water treatment, including treatments which combine UV irradiation with $\mathrm{H}_{2} \mathrm{O}_{2}$, ozone or titanium dioxide (Deng et al., 2013; Katsoyiannis et al., 2011; Prado and Esplugas 1999; Vogna et al., 2004). The UV/chlorine treatment has also gained lots of attention in recent years (Fang et al., 2014; Jin et al., 2011; Sichel et al., 2011; Wang et al., 2012; Watts et al., 2012; Xiang et al., 2016).

Photolysis of chlorine (hypochlorous acid, $\mathrm{HOCl}$, and hypochlorite ion, $\mathrm{OCl}^{-}$) by UV light produces both $\mathrm{HO}^{\circ}$ and reactive chlorine species such as $\mathrm{Cl}^{\circ}$ and $\mathrm{Cl}_{2}{ }^{-}$under 
UV irradiation, as eqs. 1-3 show (Nowell and Hoigné, 1992b).

$$
\begin{aligned}
& \mathrm{HOCl}+h v \rightarrow \mathrm{HO}^{\bullet}+\mathrm{Cl}^{\bullet} \\
& \mathrm{OCl}^{-}+h v \rightarrow \mathrm{O}^{-\bullet}+\mathrm{Cl}^{\bullet} \\
& \mathrm{O}^{-\bullet}+\mathrm{H}_{2} \mathrm{O} \rightarrow \mathrm{HO}^{\bullet}+\mathrm{OH}^{-}
\end{aligned}
$$

The UV/chlorine treatment may take advantage of $\mathrm{Cl}^{\circ}$ other than $\mathrm{HO}^{\circ} . \mathrm{HO}^{\circ}$ is non-selective, with an oxidation potential of $2.8 \mathrm{~V} . \mathrm{Cl}^{\circ}$, however, is a selective oxidant, with an oxidation potential 2.47V (Hirakawa and Nosaka 2002). $\mathrm{Cl}^{\circ}$ is highly reactive toward electron-rich structures such as aromatic, phenolic and aniline moities and toward neutral secondary and tertiary amines (Grebel et al., 2010; Nowell and Hoigné, 1992a). Pharmaceuticals and personal care products generally contain such moieties. Recent studies have demonstrated that the role of reactive chlorine species in degrading benzoic acid, trimethoprim and $N, N$-diethyl-3-methylbenzamide (DEET) during UV/chlorine oxidation should not be neglected (Fang et al., 2014; Sun et al., 2016; Wu et al., 2016).

There have been several studies demonstrating the effectiveness of UV/chlorine in attenuation of taste and odor compounds (specifically 2-methylisoborneol and geosmine), trichloroethylene, and some personal care products (Kong et al., 2016; Rosenfeldt et al., 2013; Sichel et al., 2011; Wang et al., 2012; Xiang et al., 2016). pH and oxidant doses have been observed to greatly affect the efficiency of UV/chlorine oxidation (Fang et al., 2014; Jin et al., 2011; Wang et al., 2012). It works best at a pH less than 6.5, and the degradation of micropollutants is greatly reduced with increasing $\mathrm{pH}$. Increasing the chlorine dose enhances $\mathrm{HO}^{\circ}$ formation and thus 
accelerates micropollutant degradation. The presence of bicarbonate and natural organic matter (NOM) reduces the degradation efficiency of benzoic acid (Fang et al., 2014). UV/chlorine removes $\mathrm{CBZ}$ better than $\mathrm{UV} / \mathrm{H}_{2} \mathrm{O}_{2}$ at $\mathrm{pH} 7$ and below, suggesting the involvement of $\mathrm{Cl}^{\circ}$ in $\mathrm{CBZ}$ degradation (Kong et al., 2014; Wang et al., 2016). Wang's group found that $\mathrm{CBZ}$ was degraded by both $\mathrm{HO}^{\bullet}$ and $\mathrm{Cl}^{\bullet}$ radicals acting together and that the contribution of each radical depends on the chlorine dose and $\mathrm{pH}$.

The transformation products (TPs) of CBZ have been evaluated in previous studies using UV irradiation coupled with $\mathrm{H}_{2} \mathrm{O}_{2}$ or titanium dioxide, both of which generate $\mathrm{HO}^{\circ}$ (Calza et al., 2012; Kim et al., 2009a, b; Vogna et al., 2004). The intermediates identified include 10,11-epoxycarbamazepine, acridine-9-carboxaldehyde, 10,11-trans-dihydroxy-carbamazepine, acridine and ring-opened products such as anthranilic acid, salicylic acid and catechol (De Laurentiis et al., 2012; Vogna et al., 2004). The reaction pathway involving CBZ and $\mathrm{HO}^{\bullet}$ includes the initial attack of $\mathrm{HO}^{\circ}$ on the aromatic ring or the formation of an epoxyde. That can either yield a diol or undergo heterocyclic ring opening to form a series of low molecular weight acids (De Laurentiis et al., 2012; Vogna et al., 2004). Direct medium-pressure UV photolysis of CBZ produces acridine, acridone and acridone-N-carbaldehyde at environmentally-irrelevant UV fluences (De Laurentiis et al., 2012; Kosjek et al., 2009). These TPs of CBZ are reported to be more toxic than CBZ itself (Donner et al., 2013). Carbamazepine has also been shown to be highly persistent in chlorinated water (Gibs et al., 2007; Lee and von Gunten, 2010). When 
very high concentrations of chlorine are used, monohydroxylated, epoxide, chloramide, diol and monohydroxylated chlorinated derivatives of CBZ have been identified during CBZ chlorination in amounts which vary with the $\mathrm{pH}$ (Soufan et al., 2013). No detailed assessment of the TPs from UV/chlorine treatment of CBZ has yet been published, but in one study nine non-chlorinated TPs were reported (Wang et al., 2016). The involvement of both $\mathrm{HO}^{\circ}$ and $\mathrm{Cl}^{\circ}$ may however generate chlorinated $\mathrm{TP}$ profiles.

Previous studies have been focused on the kinetics of CBZ degradation with little attention paid to the kinetics of the TPs' formation and transformation. The formation may vary under different water matrixes and treatment conditions. Probing their matrix/condition-dependent formation kinetics is of significance to improving understanding of the UV/chlorine process and to better assess their fates in and impacts to the environment.

In this study, the main TPs generated from the UV/chlorine treatment of CBZ were analyzed using high-resolution quadrupole time-of-flight (QTOF) mass spectrometry, and reaction pathways were proposed. The kinetics of CBZ degradation and the formation of representative TPs were evaluated under various operating conditions including the oxidant dose, $\mathrm{pH}$, and the presence of natural organic matter. Toxicity assessments were also conducted.

\section{Materials and methods}

\subsection{Reagents}


CBZ was obtained from Sigma (USA). The CBZ stock solution $(2.1 \mathrm{mM})$ was prepared in alkaline solutions containing $10 \mathrm{mM} \mathrm{NaOH}$ and stirred overnight. Standards for the CBZ intermediates and metabolites (I: CBZ-10,11-epoxide, CBZ-EP; II: 10,11-dihydro-10,11-trans-dihydroxy-CBZ, trans-diOH-CBZ; III: 10,11-dihydro-10,11-cis-dihydroxy-CBZ, cis-diOH-CBZ; IV: acridine, ACIN; and V: acridone) were purchased from Toronto Research Chemicals (Canada). Methanol, methyl tert-butyl ether (MTBE) and hexane were obtained from Merck (Germany). $\mathrm{NH}_{4} \mathrm{Cl}$, and $\mathrm{H}_{2} \mathrm{O}_{2}(30 \%)$ were purchased from Fuchen (China). Suwannee River NOM $(2 \mathrm{R} 101 \mathrm{~N})$ was obtained from the International Humic Substances Society. A stock free chlorine solution was prepared from 5\% sodium hypochlorite (Sigma), diluted to $1000 \mathrm{mg} / \mathrm{L}$ as $\mathrm{Cl}_{2}$. The solutions were standardized by diethyl-p-phenylene diamine ferrous titration (APHA, 2005).

\subsection{Experimental procedures}

A UV lamp housing with a collimated beam apparatus containing two $23 \mathrm{~W}$ low-pressure mercury lamps applied monochromatic UV radiation at $253.7 \mathrm{~nm}$. The light proceeded through an aperture down onto samples stirred within an open-top cylindrical crystallization dish $(7.1 \mathrm{~cm}$ diameter $\times 2 \mathrm{~cm}$ deep) nearly $0.3 \mathrm{~m}$ below. A magnetic stirrer was employed to assure uniform fluence. The surface irradiance (4.2 $\times 10^{-6}$ Einsteins $\mathrm{L}^{-1} \mathrm{~s}^{-1}$ ) was determined by iodide-iodate actinometry (Bolton and Linden, 2003).

For the UV/chlorine treatment, a desired amount of the free chlorine solution was 
spiked to the solutions immediately prior to UV irradiation. The mixtures were sampled at intervals and sodium sulfite in excess was added to each sample to quench the residual chlorine. Aliquots of $0.5 \mathrm{~mL}$ samples were filtered through $0.45 \mu \mathrm{m}$ filter membranes before analysis. For chlorination alone the procedures were the same except that no UV irradiation was applied.

A baseline chlorine dose of $5 \mathrm{mg} / \mathrm{L}(70 \mu \mathrm{M})$ was added to the $2.1 \mu \mathrm{M}$ CBZ solutions buffered at $\mathrm{pH} 7$ with $10 \mathrm{mM}$ phosphate buffer. An orthogonal matrix experimental design was used where reaction time, $\mathrm{pH}$, the chlorine doses, NOM content and ammonium- $\mathrm{N}$ were varied one parameter at a time from the baseline condition. The reaction conditions were chosen to simulate the water matrix and operational conditions that might encounter in real water treatment. The chlorine dosages were $3,5,10,15$ and $20 \mathrm{mg} / \mathrm{L} \mathrm{Cl}_{2}$. The $\mathrm{pH}$ values tested were 5, 6, 7, 8 and 9 . The reaction times varied from 0 seconds to 15 minutes, and the NOM concentrations were $1,2,5$ and $10 \mathrm{mg} / \mathrm{L}$ as DOC. The CBZ content and the concentrations of the intermediates (I-IV) in each $0.5 \mathrm{~mL}$ sample were analyzed using ultra-high performance liquid chromatography coupled with a triple-quadrupole mass spectrometer (UHPLC-MS/MS). .

To help identify CBZ's unknown TPs, a $2.1 \mathrm{mM}$ dose of chlorine was applied to $64 \mu \mathrm{M}$ CBZ solutions buffered at $\mathrm{pH} 5$ and 7 prior to UV irradiation. Samples of the oxidizing mixture were withdrawn periodically and subjected to ultra-high performance liquid chromatography coupled with a quadrupole time-of-flight mass spectrometer (UHPLC-QTOF-MS). 


\subsection{Toxicity testing}

Suspensions of Vibrio Fischeri bacteria were used for acute toxicity measurements. The details are provided in the Supplementary Material (Text SI-1).

\subsection{Analytical methods}

The chromatograph and mass spectrometer system consisted of an Agilent 1290 Infinity solvent delivery module, an Agilent 1290 Infinity autosampler, and an Agilent G6410B triple quadrupole mass spectrometer (Agilent, USA). Chromatographic separation was achieved using a Zorbax Eclipse Plus C18 column $(50 \times 2.1 \mathrm{~mm}, 1.8$ $\mu \mathrm{m})$. Mobile phase A was $0.1 \%$ formic acid in methanol, and mobile phase B was $0.1 \%$ formic acid in ultrapure water. The following gradient was used: $0-2.5 \mathrm{~min}, 40 \%$ A to 95\% A; 2.5-2.6 $\min , 95 \%$ A to $100 \%$ A; $2.63 \mathrm{~min}$, re-equilibrate with $40 \%$ A. The flow rate of the mobile phase was $0.2 \mathrm{~mL} / \mathrm{min}$ and the injected volume was $2 \mu \mathrm{L}$. The mass spectrometer was performed in positive electron-spray ionization (ESI+) mode. The precursor and product ions were observed at m/z 237 to 194 at $17 \mathrm{eV}$ and 237 to 192 at $23 \mathrm{eV}$.

The unknown products were analyzed by time-of-flight mass spectrometry using an Agilent 1290-6540 Q-TOF equipped with an Zobrax Extend-C18 column $(2.1 \times$ $100 \mathrm{~mm}, 1.8 \mu \mathrm{m}$ ). The mobile phase consisted of (A) acidified water and (B) acidified acetonitrile with $0.1 \%$ formic acid. The following gradient was applied: 0-12.25 min, 2-99\% B; 12.25-13.00 min, 99\% B; and 13.00-13.01 min, 99-2\% B. 
The spectrometer was used under both positive and negative electrospray ionization with time-of-flight mass scanning and in MS/MS $\left(\mathrm{MS}^{2}\right)$ mode. High-resolution mass spectra were first collected from $\mathrm{m} / \mathrm{z} 50-1200$ in negative and positive continuum mode with a $0.15 \mathrm{~s}$ scan time, and the suspected transformation products were fragmented in the collision cell. The ionization source was set up as a capillary voltage of $0.7 \mathrm{kV}$ with a source temperature of $140{ }^{\circ} \mathrm{C}$ and a desolvation temperature of $550{ }^{\circ} \mathrm{C}$. The sampling cone voltage was set to $35 \mathrm{~V}$, and the source offset was set at $50 \mathrm{~V}$. The collision energy for the auto MS/MS was set at 10, 20 and $40 \mathrm{~V}$. The sample volume was $20 \mu \mathrm{L}$, and all of the samples were analyzed in quadruplicate in order to ensure the accuracy and repeatability of the mass spectroscopy. Agilent's Mass Profiler Professional statistical software suite was used to assist with the identification of the products.

\subsection{Kinetics of CBZ degradation and TPs formation during UV/chlorine}

The time trends of the CBZ concentrations in the experiments were fitted assuming pseudo-first-order kinetics (Eq. 4). The time evolution of the intermediates was fitted with Eq. 5 (De Laurentiis et al., 2012).

$$
\begin{aligned}
& C_{t}=C_{0} e^{-k_{o b}, t} \\
& I_{t}=k_{\text {formation } i} C_{0}\left(k_{\text {decay }, i}-k_{o b s}\right)^{-1}\left(e^{-k_{o b}, t}-e^{-k_{\text {deca } y, t} t}\right)
\end{aligned}
$$

Here $\mathrm{C}_{0}$ is the initial concentration of $\mathrm{CBZ}, \mathrm{C}_{\mathrm{t}}$ is the CBZ concentration at the time $\mathrm{t}$, and $\mathrm{k}_{\mathrm{obs}}$ is the observed pseudo-first-order rate constant for CBZ transformation. $\mathrm{I}_{\mathrm{t}}$ is the concentration of intermediate $\mathrm{i}$ at time $\mathrm{t}$, and $\mathrm{k}_{\text {formation, } \mathrm{i}}$ is the corresponding 
first-order rate constant of its formation from CBZ. $\mathrm{k}_{\text {decay,i }}$ is the first-order rate constant of its decay.

\section{Results and discussion}

\subsection{The identified transformation products and proposed transformation} pathways

Chromatographic analysis of UV/chlorine-treated solutions followed by UHPLC-QTOF-MS revealed 24 distinct CBZ transformation products at measurable levels. Table 1 summarizes the experimental observations and the exact masses of those molecular ions, the relative mass errors, and the proposed elemental compositions of the TPs thus identified. The experimental $\mathrm{m} / \mathrm{z}$ ratios have low errors $(<1.1 \mathrm{ppm})$ compared with the exact $\mathrm{m} / \mathrm{z}$ ratios of the assigned TPs' compositions, indicating strong confidence in the assignments. The extracted ion chromatogram of the structures and the corresponding mass spectra of the molecular and fragmented ions are displayed in Figures SI-1 and SI-2 in the Supplementary Material. The assumed TPs' structures have been characterized based on high resolution TOF scan data, $\mathrm{MS}^{2}$ results and their chromatographic behaviors. $\mathrm{P}_{252 \mathrm{a}}, \mathrm{P}_{270 \mathrm{a}}, \mathrm{P}_{270 \mathrm{~b}}, \mathrm{P}_{179}$ and $\mathrm{P}_{195 a}$ were identified as CBZ-10,11-epoxide (CBZ-EP), 10,11-dihydro-10,11-trans-dihydroxy-CBZ (trans-diOH-CBZ), 10,11-dihydro-10,11-cis-dihydroxy-CBZ (cis-diOH-CBZ), acridine (ACIN) and acridone, respectively, by comparing their chromatographic retention and mass spectra with those of commercial standards. The cis and trans stereoisomers $\left(\mathrm{P}_{270 \mathrm{a}}\right.$ and 
$\mathrm{P}_{270 \mathrm{~b}}$ ) were distinguished by assessing the retention time of individual standards.

Radical quencher tests have shown that CBZ degradation in UV/chlorine treatment is apparently driven by $\mathrm{HO}^{\circ}$ and $\mathrm{Cl}^{\circ}$. $\mathrm{CBZ}$ is resistant to low pressure $\mathrm{UV}$ light and chlorine treatment alone (Wang et al., 2016). The CBZ transformation pathways of $\mathrm{UV} /$ chlorine treatment involving the reactions with $\mathrm{HO}^{\circ}$ and $\mathrm{Cl}^{\circ}$ are provided in Scheme 1 and 2.

\subsubsection{Hydroxyl radicals attack the 10,11-double bond of CBZ}

The CBZ molecule's 10,11-double bond is very reactive and easily attacked by $\mathrm{HO}^{\bullet}$ and other oxidizing reagents (Calza et al., 2012; Hübner et al., 2014; Yang et al., 2016). Two primary products, $P_{252 a}$ and $P_{252 b}$, were observed at $\mathrm{m} / \mathrm{z} 253.0977$ and 253.0974, respectively. These are illustrated in Scheme 1. The two observed masses correspond to a chemical formula of $\mathrm{C}_{15} \mathrm{H}_{12} \mathrm{~N}_{2} \mathrm{O}_{2}$ with a relative mass error of $0.3 \mathrm{ppm}$ (Table 1). The corresponding $\mathrm{MS}^{2}$ results illustrate that the two $[\mathrm{M}+\mathrm{H}]^{+}$ions generated fragments at $\mathrm{m} / \mathrm{z}$ of 236.0706, 210.0912, and 180.0808 (Figure SI-2). $\mathrm{P}_{252 \mathrm{a}}$ was confirmed to be CBZ-EP using the standard, and it was apparently formed from oxidation by $\mathrm{HO}^{\circ}$. The structure of $\mathrm{P}_{252 \mathrm{a}}$ has also been detected as a degradation product of CBZ by ozone, photocatalytic oxidation and fenton-like reactions (Ahmed and Chiron 2014; Hübner et al., 2014; Jian et al., 2013; Martínez et al., 2011; Rao et al., 2014). The two fragments of $\mathrm{P}_{252 \mathrm{~b}}$ at $\mathrm{m} / \mathrm{z}$ of 236.0706 and 210.0912 indicate the loss of ammonia $\left(-\mathrm{NH}_{3}\right)$ and cyanic acid $(-\mathrm{HOCN})$, respectively. Neither the loss of a hydroxyl group nor a water molecule was observed, which allows excluding the 
pathway of hydroxylation of the aromatic ring. $\mathrm{P}_{252 \mathrm{~b}}$ was thus assigned as carbamazepine-9-carboxaldehyde, which may be formed through $\mathrm{HO}^{\bullet}$ attack on the $\mathrm{C}_{10}-\mathrm{C}_{11}$ double bond followed by a seven-membered ring opening and the resulting labile intermediates would suffer facile ring contraction as illustrated in Figure SI-3 (Chiron et al., 2006; Petrovic and Barceló, 2007).

$\mathrm{P}_{252 \mathrm{a}}$ might undergo hydrolysis to generate $\mathrm{P}_{270 \mathrm{a}}$ and $\mathrm{P}_{270 \mathrm{~b}} \quad($ cis and trans-diOH-CBZ), both were confirmed by the standards (De Laurentiis et al., 2012). $\mathrm{P}_{252 \mathrm{~b}}$ may undergo intramolecular cyclization to form $\mathrm{P}_{250}$, a pathway that was also reported during $\mathrm{UV} / \mathrm{H}_{2} \mathrm{O}_{2}$ oxidation of $\mathrm{CBZ}$ (Keen et al., 2012). The two secondary oxidation products, assigned to $\mathrm{P}_{266 \mathrm{a}}$ and $\mathrm{P}_{266 \mathrm{~b}}$ respectively, were observed at $\mathrm{m} / \mathrm{z}$ of 267.0770 and illustrated in Scheme 1. The two observed masses correspond to a chemical formula of $\mathrm{C}_{15} \mathrm{H}_{10} \mathrm{~N}_{2} \mathrm{O}_{3}$ with relative mass errors of 0.7 and $0.0 \mathrm{ppm}$, respectively (Table 1). The $\mathrm{MS}^{2}$ result for $\mathrm{P}_{266 \mathrm{a}}$, yielded two predominant fragments at 226.0863 and 180.0808, indicating the loss of $\mathrm{CH}_{2} \mathrm{O}_{2}$ and the presence of carboxylic groups (Figure SI-2). This suggests that $\mathrm{P}_{266 a}$ may form through the oxidation of aldehyde $\mathrm{P}_{250}$ to its corresponding carboxylic acid. The reaction mechanism from aldehyde to carboxylic acid has been previously reported in the treatment of CBZ by UV/TiO 2 photocatalysis (Martínez et al., 2011; Calza et al., 2012), where hydroxyl radical plays a key role. And the assigned structure of $\mathrm{P}_{266 \mathrm{~b}}$ may arise from the direct addition of carbonyl groups on CBZ (Chiron et al., 2006), and was eluted as a relative polar compound with a weaker retention on the chromatographic column ( $\mathrm{RT}=1.36$ min, Table 1). But no $\mathrm{MS}^{2}$ spectra were obtained due to its low abundance. Both $\mathrm{P}_{266 \mathrm{a}}$ 
and $\mathrm{P}_{266 \mathrm{~b}}$ are relatively resistant to further oxidation and their concentrations kept accumulating with increasing reaction time (data not shown).

\subsubsection{Hydroxyl and chlorine radicals attack the transformation products}

Two products $\left(\mathrm{P}_{225 \mathrm{a}}\right.$ and $\left.\mathrm{P}_{225 \mathrm{~b}}\right)$ were identified at $\mathrm{m} / \mathrm{z} 226.0862$ and assigned a molecular formula of $\mathrm{C}_{14} \mathrm{H}_{11} \mathrm{NO}_{2}$ with relative mass errors of 0.7 and $0.1 \mathrm{ppm}$, respectively (Table 1). They yielded the same fragment ions with $\mathrm{m} / \mathrm{z}$ of 208.0753 and 180.0806 at lower collision energy (CE) voltage (10 and $20 \mathrm{~V})$, indicating the loss of a water molecule and a $\mathrm{CO}$ group. This suggests the presence of a hydroxyl group in the aromatic rings. In consideration of the shift in the retention times between $\mathrm{P}_{225}$ (4.09 $\mathrm{min}$ ) and $\mathrm{P}_{225 \mathrm{~b}}(0.81 \mathrm{~min}), \mathrm{P}_{225 \mathrm{a}}$ was proposed to contain a $\mathrm{N}=\mathrm{C}$ double bond, which may tautomerize to $\mathrm{P}_{225 b}$ by restoring the aromaticity in the right ring (Scheme 2). And the loss of one water molecule from $P_{225 a}$ and $P_{225 b}$ may form $P_{207}$.

Two products $\left(\mathrm{P}_{195 \mathrm{a}}, \mathrm{P}_{195 \mathrm{~b}}\right)$ were identified at $\mathrm{m} / \mathrm{z} 196.0753$ and they were assigned a molecular formula of $\mathrm{C}_{13} \mathrm{H}_{9} \mathrm{NO}$ with relative mass errors of $0.3 \mathrm{ppm}$. Both yielded predominant fragments at $\mathrm{m} / \mathrm{z}$ of 167.0726 at a CE voltage of $40 \mathrm{~V}$ (Figure SI-2). $\mathrm{P}_{195 a}$ was identified as acridone using the standard, and the structure assigned to $\mathrm{P}_{195 \mathrm{~b}}$ is shown in Table 1 and Scheme 2 . Further attack on $\mathrm{P}_{195 a}$ by $\mathrm{HO}^{\circ}$ led to the formation of $\mathrm{P}_{211}$ and continuous oxidation and chlorination of the hydroxylated derivative yielded the corresponding chlorinated ketone, $\mathrm{P}_{245}$.

$\mathrm{P}_{179}$ was identified as acridine using the standard. It may be involved from the decarbonylation of $\mathrm{P}_{195 \mathrm{a}}$ and the elimination of carboxaldehyde from $\mathrm{P}_{207}$. Further 
attack by $\mathrm{HO}^{\bullet}$ may degrade it to ring cleavage products such as anthranilic acid, salicylic acid and catechol (Vogna et al., 2004). As Figure 1 shows, the abundance of $\mathrm{P}_{179}$ first increased, and then decreased with increasing reaction time.

\subsubsection{Chlorine radical attacks the 10,11-double bonds and benzene rings of CBZ} and TPs

Both $\mathrm{P}_{270 \mathrm{c}}$ and $\mathrm{P}_{270 \mathrm{~d}}$ had the formula $\mathrm{C}_{15} \mathrm{H}_{11} \mathrm{~N}_{2} \mathrm{OCl}$ with a relative mass error of $0.3 \mathrm{ppm}$. They shared the same major fragment ions at $\mathrm{m} / \mathrm{z} 228.0575$ and 193.0883, which indicates the loss of one $\mathrm{Cl}$ atom and that the tricyclic structure of $\mathrm{CBZ}$ remained intact. These results suggest the direct substitution of hydrogen by chlorine on CBZ. To find the position of the substituted chlorine, an optimum collision energy-dependent ESI-tqMS method reported by Deng was applied (Deng et al., 2014). That method is able to designate the position of chlorine substitution in the aliphatic part and in the benzene ring of an organic molecule by obtaining their corresponding ranges of optimum collision energy. In this case they were $5-7 \mathrm{eV}$ and over $15 \mathrm{eV}$, respectively, in the precursor ion scan of m/z 35. Figure SI-5 shows that the optimum collision energies of $\mathrm{P}_{270 \mathrm{c}}$ and $\mathrm{P}_{270 \mathrm{~d}}$ in the precursor ion scan of $\mathrm{m} / \mathrm{z} 35$ were $10 \mathrm{eV}$ and $20 \mathrm{eV}$, respectively, suggesting that the chlorine substituted in the aromatic rings instead of in the amine structure. Thus, the chlorine was positioned either on benzene ring or on the $\mathrm{C}_{10}-\mathrm{C}_{11}$ double bond of the seven-membered ring. Besides $\mathrm{P}_{270 \mathrm{c}}$ and $\mathrm{P}_{270 \mathrm{~d}}$, there were four other TPs $\left(\mathrm{P}_{229 \mathrm{a}}, \mathrm{P}_{229 \mathrm{~b}}, \mathrm{P}_{245}\right.$, and $\left.\mathrm{P}_{259}\right)$ containing a chlorine atom in their molecules. Their time evolution profiles are shown 
in Figure SI-4. $\mathrm{P}_{229 \mathrm{a}}(\mathrm{RT}=3.09 \mathrm{~min})$ and $\mathrm{P}_{229 \mathrm{~b}}(\mathrm{RT}=3.43 \mathrm{~min})$ were observed with $\mathrm{m} / \mathrm{z}$ of 230.0365 and are illustrated in Scheme 2. The two observed exact masses correspond to a chemical formula of $\mathrm{C}_{13} \mathrm{H}_{8} \mathrm{NOCl}$ with relative mass errors of 0.2 and $0.3 \mathrm{ppm}$, respectively (Table 1 ). The $\mathrm{MS}^{2}$ results for the two compounds yielded the same fragment ions with $\mathrm{m} / \mathrm{z}$ of 195.0676 and 167.0724, which was also observed in the fragments of $\mathrm{P}_{195 \mathrm{a}}$ (Figure SI-2). Thus $\mathrm{P}_{229 \mathrm{a}}$ and $\mathrm{P}_{229 \mathrm{~b}}$ may originate from the chlorination of $\mathrm{P}_{195 \mathrm{a}}$. By applying the same optimum collision energy-dependent ESI-tqMS method, the optimum collision energies of the $\mathrm{P}_{229 \mathrm{a} / \mathrm{b}}$ in the precursor ion scan of m/z 35 were $7 \mathrm{eV}$ and $20 \mathrm{eV}$, respectively (Figure SI-5), indicating that the chlorine was substituted for a hydrogen in the amine structure and in the aromatic ring, respectively. A chemical formula of $\mathrm{C}_{13} \mathrm{H}_{8} \mathrm{NO}_{2} \mathrm{Cl}$ is proposed for $\mathrm{P}_{245}$ with a relative mass error of $0.4 \mathrm{ppm}$. The mass spectra yielded fragmented ions at $\mathrm{m} / \mathrm{z}$ of 211.0618 , 182.0593 and 154.0651, which indicates the presence of one $\mathrm{Cl}$ atom and two ketone groups. The chlorine is probably attached to the $\mathrm{N}$ atom as the optimum collision energy in the precursor ion scan of $\mathrm{m} / \mathrm{z} 35$ was $5 \mathrm{eV}$ (Figure $\mathrm{SI}-5$ ). $\mathrm{P}_{259}$ is characterized as having the chemical formula $\mathrm{C}_{14} \mathrm{H}_{11} \mathrm{NO}_{2} \mathrm{Cl}$ with a relative mass error of 0.6ppm. It may be formed via chlorine attack on the benzene ring of $\mathrm{P}_{225 \mathrm{~b}}$ (Scheme 2).

In order to distinguish the role of chlorine radicals, a monochloramine $\left(\mathrm{NH}_{2} \mathrm{Cl}\right)$ solution was irradiated under UV light. This system is known to generate mainly $\mathrm{Cl}^{*}$ and the unreactive $\mathrm{NH}_{2}$ radicals (Zhang et al., 2015). The major TPs of CBZ under the UV/ $\mathrm{NH}_{2} \mathrm{Cl}$ treatment included $\mathrm{P}_{179}$ (acridine), $\mathrm{P}_{195 \mathrm{a}}$ (acridone), $\mathrm{P}_{207}$ and $\mathrm{P}_{229 \mathrm{a}}$, and a 
trace of $\mathrm{P}_{252 \mathrm{a}}$ was also detected. The time evolution profiles of those products are shown in Figure SI-6. Those TPs were generated at much lower levels than in UV/chlorine treatment (Figure 1). CBZ-EP $\left(\mathrm{P}_{252 \mathrm{a}}\right)$, the compound with the highest peak in the UV/chlorine process, occurred in only minor concentrations in the $\mathrm{UV} / \mathrm{NH}_{2} \mathrm{Cl}$ process, indicating that $\mathrm{HO}^{\circ}$ plays a minor role in the $\mathrm{UV} / \mathrm{NH}_{2} \mathrm{Cl}$ process. The generation of $\mathrm{P}_{179}, \mathrm{P}_{195 \mathrm{a}}, \mathrm{P}_{207}$ and $\mathrm{P}_{229 \mathrm{a}}$ suggests that they can be formed from the pathway involving $\mathrm{Cl}^{\circ}$ as proposed in Scheme 1 and 2 .

\subsection{Quantification of the TPs and the kinetics}

No commercial standard is available for most of the TPs identified. Commercial standards are available for $\mathrm{P}_{252 \mathrm{a}}$ (I: CBZ-EP), $\mathrm{P}_{270 \mathrm{a}}$ (II: trans-diOH-CBZ), $\mathrm{P}_{270 b}$ (III: cis-diOH-CBZ) and $\mathrm{P}_{179}$ (IV: ACIN). They were used to quantify those species during CBZ degradation.

Figure 2 displays the generation of these TPs along with CBZ degradation during the UV/chlorine treatment. TPs I, II, III and IV all showed an increase followed by a decreasing trend as the reaction progressed. I (CBZ-EP) had the highest yield $(0.23$ $\mu \mathrm{M})$ after 5 minutes when $80 \%$ of the CBZ had been converted. This corresponds to a CBZ-EP transformation yield of $13.6 \%$. The yield of III (cis-diOH-CBZ) was about $39 \pm 4 \%$ of that of II (trans-diOH-CBZ). IV (ACIN) had the lowest yields, in the range of $0.01 \mu \mathrm{M}$, after 5 minutes of treatment. But it is known to be more toxic than CBZ (Donner et al., 2013). The observed TPs arise through different reaction pathways as Scheme 1 shows. I was generated from $\mathrm{HO}^{\bullet}$ reactions. IV was generated from 
reactions involving both $\mathrm{HO}^{\circ}$ and $\mathrm{Cl}^{\circ}$. The formation of the TPs depend on the relative formation and decomposition rates, which are expected to be affected by reaction conditions such as the $\mathrm{pH}$, chlorine content and other solutes in the aqueous medium. I (CBZ-EP) and IV (ACIN) were thus quantified at different chlorine doses, pHs and NOM contents to better understand the formation and decay kinetics of the TPs during CBZ degradation.

\subsubsection{Chlorine doses}

The observed pseudo-first-order degradation rate constants of CBZ $\left(\mathrm{k}_{\mathrm{obs}}\right)$ increased linearly with increasing chlorine dose (Figure SI-7). As the dose increased from $70 \mu \mathrm{M}(5 \mathrm{mg} / \mathrm{L})$ to $282 \mu \mathrm{M}(20 \mathrm{mg} / \mathrm{L}), \mathrm{k}_{\text {obs }}$ increased 3.6 times from $5.2 \times 10^{-3}$ to $13.4 \times 10^{-3} \mathrm{~s}^{-1}$. As more chlorine was present, more hydroxyl and chlorine radicals were generated (Fang et al., 2014; Wang et al., 2016).

The time evolution of TPs I and IV in the UV/chlorine treatment at various chlorine doses is shown in Figure 3 (b and c). I and IV levels at first increased, then decreased with prolonged reaction time. The accumulated amounts of $\mathbf{I}$ were higher at higher chlorine dosages. The maximum $0.49 \mu \mathrm{M}$ concentration of I was recorded at a chlorine dose of $282 \mu \mathrm{M}(20 \mathrm{mg} / \mathrm{L})$ after 2 minutes of treatment, at which point $77 \%$ of the CBZ had been degraded. This corresponded to a CBZ-EP transformation yield of $30 \%$. The accumulated amounts of IV, however, decreased with increasing chlorine dosage. After $10 \mathrm{~min}$ of irradiation the concentration of IV was $0.0085 \mu \mathrm{M}$ in a 5 $\mathrm{mg} / \mathrm{L} \mathrm{Cl}_{2}$ solution and $0.0029 \mu \mathrm{M}$ with a $20 \mathrm{mg} / \mathrm{L}$ solution. 
The formation and decomposition rates of $\mathbf{I}$ were obtained by fitting the data using Equation 6 (Table 2). Linear relationships were observed between the decay rate of CBZ and the $\mathrm{k}_{\text {formation,I }}$ with the chlorine dosage (Figure SI-8). The $\mathrm{k}_{\text {formation,I }}$ was about $27 \pm 5 \%$ of $\mathrm{k}_{\mathrm{obs}, \mathrm{CBZ}}$. Under UV irradiation, the $\mathrm{HO}^{\circ}$ concentration increased with increases in the chlorine concentration. It is thus to be expected that the $\mathrm{k}_{\text {formation, } \mathrm{I}}$ would increase because I is formed through the reaction of $\mathrm{CBZ}$ with $\mathrm{HO}^{\circ}$. The values of $\mathrm{k}_{\text {decay,I }}$ did not exhibit dependence on chlorine dose. The formation and decay constants for IV increased by $10 \%$ and $14 \%$ respectively when the chlorine dose was increased from 70 to $211 \mu \mathrm{M}$. The sum of the formation constants for I, II, III (data not shown) and IV together accounted for about $34.5 \%$ of the overall transformation of CBZ $\left(\mathrm{k}_{\mathrm{obs}}\right)$, supporting the existence of other transformation pathways.

\subsection{2 $\mathrm{pH}$}

As the $\mathrm{pH}$ increased from 5 to 9 , the $\mathrm{k}_{\mathrm{obs}}$ of CBZ decreased (Figure SI-9) from $8.6 \times 10^{-3} \mathrm{~s}^{-1}$ at $\mathrm{pH} 5$ to $3.1 \times 10^{-3} \mathrm{~s}^{-1}$ at $\mathrm{pH}$ 9. These results are consistent with observations in previous studies using 2-methylisoborneol, trichloroethylene and benzoic acid as target compounds (Fang et al., 2014; Wang et al., 2012; Watts et al., 2012). At higher $\mathrm{pH}, \mathrm{HO}^{\circ}$ and $\mathrm{Cl}^{\bullet}$ concentrations are lower during the $\mathrm{UV} /$ chlorine treatment due to the lower quantum yields of $\mathrm{OCl}^{-}$. It is also attributed to that $\mathrm{OCl}^{-}$has higher radical scavenging rate compared with $\mathrm{HOCl}$.

The evolution of I and IV during UV/chlorine treatment of CBZ at different $\mathrm{pHs}$ is shown in Figure 3(e and f). The accumulated $\mathbf{I}$ concentration peaked (at $0.23 \mu \mathrm{M}$ ) 
after 5 min of irradiation at $\mathrm{pH} 7$. At pH 5 and 9 the peak values were 0.017 and 0.21 $\mu \mathrm{M}$, respectively. The values of $\mathrm{k}_{\text {decay, } \mathrm{I}}$ decreased with increasing $\mathrm{pH}$ and they were $16.5 \times 10^{-3}, 2.4 \times 10^{-3}$ and $1.4 \times 10^{-3} \mathrm{~s}^{-1}$ at $\mathrm{pH} 5,7$ and 9 , respectively. This is due to the reaction of $\mathbf{I}$ with $\mathrm{HO}^{\bullet}$ radicals, which were at higher concentrations at $\mathrm{pH} 5$ than in neutral and alkaline conditions. However, the $\mathrm{k}_{\text {formation,I }}$ increased as $\mathrm{pH}$ increased from 5 to 7 , but decreased when the $\mathrm{pH}$ was 9. One possible reason is that $\mathrm{CBZ}$ degradation pathways other than via I were favored at $\mathrm{pH}$ 5. The QTOF analysis showed that $\mathrm{P}_{252 \mathrm{~b}}$, which was not observed at $\mathrm{pH} 7$, was clearly identified at $\mathrm{pH} 5$. Ring contraction involved in the formation of $\mathrm{P}_{252 \mathrm{~b}}$ resulting from a hydroxylation step at the $\mathrm{C}_{10}$ position appeared to be more active in acid conditions (Figure SI-3). The accumulated IV concentrations at $\mathrm{pH} 5,7$ and 9 were $0.0002,0.0085$ and 0.014 $\mu \mathrm{M}$, respectively after $10 \mathrm{~min}$ of UV/chlorine treatment. So the kinetics showed a significant dependence on $\mathrm{pH}$ (Table 2). As with $\mathbf{I}$, the $\mathrm{k}_{\text {decay,IV were also much higher }}$ in acid solutions. $\mathrm{k}_{\text {formation,IV }}$ also increased as $\mathrm{pH}$ decreased.

\subsubsection{NOM}

$\mathrm{NOM}$ at 5 or $10 \mathrm{mgC} / \mathrm{L}$ greatly retarded the degradation of CBZ (Figure SI-10). The $\mathrm{k}_{\mathrm{obs}}$ decreased to $2.0 \times 10^{-3} \mathrm{~s}^{-1}$ and $1.2 \times 10^{-3} \mathrm{~s}^{-1}$ at the two NOM concentrations (Table 2). NOM absorbs UV light at $254 \mathrm{~nm}$, thus reducing the radiation available for generating radicals, as eqs. 1 and 2 show. Additionally, NOM reacts with free chlorine at a vigorous initial reaction rate of 500-5000 $\mathrm{M}^{-1} \mathrm{~s}^{-1}$, slowing to 0.7-5 $\mathrm{M}^{-1} \mathrm{~s}^{-1}$ (Westerhoff et al., 2004). More chlorine was thus consumed by NOM at higher 
concentrations. NOM is also a $\mathrm{HO}^{\circ}$ scavenger and a reaction rate of $2.5 \times 10^{4} \mathrm{mg} \mathrm{L}^{-1} \mathrm{~s}^{-1}$ has been reported (Mertens and von Sonntag, 1995). In these experiments too, the presence of NOM greatly reduced the radical concentrations.

NOM retarded the formation of I (Figure SI-11). After 10min of irradiation, the concentration of I was $0.18 \mu \mathrm{M}$ in the absence of NOM, but was only $0.07 \mu \mathrm{M}$ in the presence of $10 \mathrm{mgC} / \mathrm{L} \mathrm{NOM}$, which corresponded to a reduction of molar yield of $\mathbf{I}$ from $8 \%$ to $6.6 \%$. The presence of NOM also retarded the formation of IV initially, but beyond $10 \mathrm{~min}$ the $\mathbf{I V}$ concentration reached $0.0085 \mu \mathrm{M}$ in the presence of 10 $\mathrm{mgC} / \mathrm{L}$ NOM, which was much higher than that formed in the absence of NOM $(0.021 \mu \mathrm{M})$. Since the presence of NOM reduced the levels of $\mathrm{HO}^{\circ}$ and $\mathrm{Cl}^{\circ}$, that reduced the transformation of ACIN to ring open products. As a result, the presence of NOM promoted the accumulation of IV.

\subsection{Toxicity}

The toxicity of the products was assayed by evaluating the inhibition of bioluminescence of the bacterium Vibrio Fischeri. As shown in Figure SI-12, during the first $5 \mathrm{~min}$ of the UV/chlorine treatment the inhibition of Vibrio Fischeri bioluminescence showed a slight increase. Acridine and acridone are known to be carcinogenic and significantly more toxic than CBZ (Parkhurst et al., 1981; Wiegman et al., 2002). Donner et al (2013) indicated that the ecotoxicity increased during 90 min UV treatment of $6 \mathrm{mg} / \mathrm{L} \mathrm{CBZ} \mathrm{based} \mathrm{on} \mathrm{Vibrio} \mathrm{fischeri,} \mathrm{Pseudokirchneriella}$ subcapitata and Daphnia magna testings. But one study also reported that the acute 
toxicity of CBZ on clam was not shown to increase during the solar irradiation, maybe due to the much lower initial concentrations of CBZ $(0-9 \mu \mathrm{g} / \mathrm{L})$ used in the tests (Almeida et al., 2016). Moreover, chlorinated products may also have some toxicity (Plewa et al., 2012). As the UV irradiation time further increased to $15 \mathrm{~min}$, the inhibition of Vibrio Fischeri bioluminescence decreased greatly in tandem with the decreasing TP formation (Figure 2). Therefore, providing enough reaction time therefore seems to promote the further degradation and detoxification of the toxic products.

\section{Conclusions}

The degradation of CBZ in the UV/chlorine treatment is initiated by the attack of hydroxyl and chlorine radicals on the 10,11-double bond or the aromatic ring of the CBZ molecule. The intermediates then undergo hydroxylation, hydrogen atom abstraction, acylamino cleavage and decarboxylation reactions to generate smaller molecular weight products such as acridine and acridone. Five chlorine substituted products were identified, and the substitution on both the aromatic ring and the $\mathrm{N}$ atom was observed. Four degradation products were quantified, accounting for $34.5 \%$ of the molar balance. The transformation kinetics and peak yields of CBZ-EP and acridine showed different dependence on the reaction conditions including chlorine dose, $\mathrm{pH}$ and NOM concentration because of their different reaction pathways. The toxicity tests indicated that the toxicity of the reaction intermediates decreases as they are converted to the final products. 


\section{Acknowledgements:}

We thank the National Science Foundation of China (grants 21622706 and 21577178), Guangdong's Natural Science Funds for Distinguished Young Scholars (grant 2015A030306017), and the Science and Technology Planning Project of Guangdong Province (grant 2014A020216010) for their financial support of this study.

\section{References}

Ahmed, M.M. and Chiron, S. (2014) Solar photo-Fenton like using persulphate for carbamazepine removal from domestic wastewater. Water Res. 48(1), 229-236.

Almeida, Â., Calisto, V., Domingues, M.R., Esteves, V.I., Schneider, R.J., Soares, A.M., Figueira, E. and Freitas, R. (2016) Comparison of the toxicological impacts of carbamazepine and a mixture of its photodegradation products in scrobicularia plana. J. Hazard. Mater. 323, 220-232

Andreozzi, R., Marotta, R., Pinto, G., Pollio, A. (2002) Carbamazepine in water: Persistence in the environment, ozonation treatment and preliminary assessment on algal toxicity. Water Res. 36(11), 2869-2877.

APHA (2005) Standard methods for the examination of water and wastewater. American Public Health Association (APHA): Washington, DC, USA.

Bolton, J.R., Linden, K.G. (2003) Standardization of methods for fluence (UV dose) determination in bench-scale UV experiments. J. Environ. Eng. 129, 209-215.

Calza, P., Medana, C., Padovano, E., Giancotti, V., Baiocchi, C. (2012) Identification of the unknown transformation products derived from clarithromycin and carbamazepine using liquid chromatography/high-resolution mass spectrometry. Rapid. Commun. Mass. Spectrom. 26, 1687-1704.

Chiron, S., Minero, C., Vione, D. (2006) Photodegradation processes of the 
antiepileptic drug carbamazepine, relevant to estuarine waters. Environ. Sci. Technol. 40(19), 5977-5983.

De Laurentiis, E., Chiron, S., Kouras Hadef, S., Richard, C., Minella, M., Maurino, V., Minero, C., Vione, D. (2012) Photochemical fate of carbamazepine in surface freshwaters: Laboratory measures and modeling. Environ. Sci. Technol. 46(15), 8164-8173.

Deng, J., Shao, Y., Gao, N., Xia, S., Tan, C., Zhou, S., Hu, X. (2013) Degradation of the antiepileptic drug carbamazepine upon different UV-based advanced oxidation processes in water. Chem. Eng. J. 222, 150-158.

Deng, Z., Yang, X., Shang, C. and Zhang, X. (2014) Electrospray Ionization-Tandem Mass Spectrometry Method for Differentiating Chlorine Substitution in Disinfection Byproduct Formation. Environ. Sci. Technol. 48(9), 4877-4884.

Donner, E., Kosjek, T., Qualmann, S., Kusk, K.O., Heath, E., Revitt, D.M., Ledin, A., Andersen, H.R. (2013) Ecotoxicity of carbamazepine and its UV photolysis transformation products. Sci. Total. Environ 443, 870-876.

Fang, J., Fu, Y., Shang, C. (2014) The roles of reactive species in micropollutant degradation in the UV/free chlorine system. Environ. Sci. Technol. 48(3), 1859-1868.

Gibs, J., Stackelberg, P.E., Furlong, E.T., Meyer, M., Zaugg, S.D., Lippincott, R.L. (2007) Persistence of pharmaceuticals and other organic compounds in chlorinated drinking water as a function of time. Sci. Total. Environ. 373(1), 240-249.

Grebel, J.E., Pignatello, J.J., Mitch, W.A. (2010) Effect of halide ions and carbonates on organic contaminant degradation by hydroxyl radical-based advanced oxidation processes in saline waters. Environ. Sci. Technol. 44(17), 6822-6828.

Hübner, U., Seiwert, B., Reemtsma, T., Jekel, M. (2014) Ozonation products of carbamazepine and their removal from secondary effluents by soil aquifer treatment: Indications from column experiments. Water Res. 49, 34-43.

Hirakawa, T., Nosaka, Y. (2002) Properties of $\mathrm{O}_{2} \bullet^{-}$and $\mathrm{OH} \bullet$ formed in $\mathrm{TiO}_{2}$ aqueous suspensions by photocatalytic reaction and the influence of $\mathrm{H}_{2} \mathrm{O}_{2}$ and some ions. Langmuir 18(8), 3247-3254.

Huerta-Fontela, M., Galceran, M.T., Ventura, F. (2011) Occurrence and removal of pharmaceuticals and hormones through drinking water treatment. Water Res. 45(3), 1432-1442. 
Jelic, A., Gros, M., Ginebreda, A., Cespedes Sanchez, R., Ventura, F., Petrovic, M., Barcelo, D. (2011) Occurrence, partition and removal of pharmaceuticals in sewage water and sludge during wastewater treatment. Water Res. 45(3), 1165-1176.

Jian, X., Lei, L., Guo, C., Yuan, Z. and Wei, M. (2013) Photocatalytic degradation of carbamazepine by tailored $\mathrm{BiPO}_{4}$ : Efficiency, intermediates and pathway. Appl. Catal. B. 130-131(6), 285-292.

Jin, J., El Din, M.G., Bolton, J.R. (2011) Assessment of the UV/chlorine process as an advanced oxidation process. Water Res. 45(4), 1890-1896.

Katsoyiannis, I.A., Canonica, S., von Gunten, U. (2011) Efficiency and energy requirements for the transformation of organic micropollutants by ozone, $\mathrm{O}_{3} / \mathrm{H}_{2} \mathrm{O}_{2}$ and $\mathrm{UV} / \mathrm{H}_{2} \mathrm{O}_{2}$. Water Res. 45(13), 3811-3822.

Keen, O.S., Baik, S., Linden, K.G., Aga, D.S. and Love, N.G. (2012) Enhanced biodegradation of carbamazepine after $\mathrm{UV} / \mathrm{H}_{2} \mathrm{O}_{2}$ advanced oxidation. Environ. Sci. Technol. 46(11), 6222-6227.

Kim, I., Yamashita, N., Tanaka, H. (2009a) Performance of UV and UV/ $\mathrm{H}_{2} \mathrm{O}_{2}$ processes for the removal of pharmaceuticals detected in secondary effluent of a sewage treatment plant in Japan. J. Hazard. Mater. 166(2-3), 1134-1140.

Kim, I., Yamashita, N., Tanaka, H. (2009b) Photodegradation of pharmaceuticals and personal care products during $\mathrm{UV}$ and $\mathrm{UV} / \mathrm{H}_{2} \mathrm{O}_{2}$ treatments. Chemosphere 77(4), $518-525$.

Kolpin, D.W., Furlong, E.T., Meyer, M.T., Thurman, E.M., Zaugg, S.D., Barber, L.B., Buxton, H.T. (2002) Pharmaceuticals, hormones, and other organic wastewater contaminants in US streams, 1999-2000: A national reconnaissance. Environ. Sci. Technol. 36(6), 1202-1211.

Kong, D.Z., Shang, C., Yang, X., Fang, J.Y. (2014) Comparison of DBP formation from the UV/chlorine and $\mathrm{UV} / \mathrm{H}_{2} \mathrm{O}_{2}$ processes at equivalent removal of carbamazepine and atrazine. Abstracts of Papers of the American Chemical Society, 248th National Meeting \& Exposition, San Francisco, CA, August 10-14.

Kong, X., Jiang, J., Ma, J., Yang, Y., Liu, W., Liu, Y. (2016) Degradation of atrazine by UV/chlorine: Efficiency, influencing factors, and products. Water Res. 90, 15-23.

Kosjek, T., Andersen, H.R., Kompare, B., Ledin, A., Heath, E. (2009) Fate of carbamazepine during water treatment. Environ. Sci. Technol. 43(16), 6256-6261. 
Lee, Y., von Gunten, U. (2010) Oxidative transformation of micropollutants during municipal wastewater treatment: Comparison of kinetic aspects of selective (chlorine, chlorine dioxide, ferratevi, and ozone) and non-selective oxidants (hydroxyl radical). Water Res. 44(2), 555-566.

Martínez, C.M.C.L., Fernández, M.I., Santaballa, J.A., Faria, J. (2011) Kinetics and mechanism of aqueous degradation of carbamazepine by heterogeneous photocatalysis using nanocrystalline $\mathrm{TiO}_{2}, \mathrm{ZnO}$ and multi-walled carbon nanotubes-anatase composites. Appl. Catal. B. 102(3-4), 563-571.

Mertens, R., von Sonntag, C. (1995) Photolysis $(\lambda=254 \mathrm{~nm})$ of tetrachloroethene in aqueous solutions. J. Photochem. Photobiol., A 85(1-2), 1-9.

Miao, X.S., Metcalfe, C.D. (2003) Determination of carbamazepine and its metabolites in aqueous samples using liquid chromatography-electrospray tandem mass spectrometry. Anal. Chem. 75(15), 3731-3738.

Mohapatra, D.P., Brar, S.K., Tyagi, R.D., Picard, P., Surampalli, R.Y. (2014) Analysis and advanced oxidation treatment of a persistent pharmaceutical compound in wastewater and wastewater sludge: Carbamazepine. Sci. Total. Environ. 470-471, $58-75$.

Nowell, L.H., Hoigné, J. (1992a) Photolysis of aqueous chlorine at sunlight and ultraviolet wavelengths I: Degradation rates. Water. Res. 26(5), 593-598.

Nowell, L.H., Hoigné, J. (1992b) Photolysis of aqueous chlorine at sunlight and ultraviolet wavelengths II: Hydroxyl radical production. Water. Res. 26(5), 599-605.

Parkhurst, B.R., Bradshaw, A.S., Forte, J.L. and Wright, G.P. (1981) The chronic toxicity to daphnia magna of acridine, a representative azaarene present in synthetic fossil fuel products and wastewaters . Environ. Pollut. 24(1), 21-30.

Petrovic, M., Barceló, D. (2007) LC-MS for identifying photodegradation products of pharmaceuticals in the environment. Trends Anal. Chem. 26(6), 486-493.

Plewa, M.J., Wagner, E.D., Metz, D.H., Kashinkunti, R., Jamriska, K.J., Meyer, M. (2012) Differential toxicity of drinking water disinfected with combinations of ultraviolet radiation and chlorine. Environ. Sci. Technol. 46(14), 7811-7817.

Prado, J., Esplugas, S. (1999) Comparison of different advanced oxidation processes involving ozone to eliminate atrazine. Ozone Sci. Eng. 21(1), 39-52.

Rao, Y.F., Qu, L., Yang, H. and Chu, W. (2014) Degradation of carbamazepine by $\mathrm{Fe}(\mathrm{II})$-activated persulfate process. J. Hazard. Mater. 268(6), 23-32. 
Rosenfeldt, E., Boal, A.K., Springer, J., Stanford, B., Rivera, S., Kashinkunti, R.D., Metz, D.H. (2013) Comparison of UV-mediated advanced oxidation. J. Am. Water Works Assoc. 105(7), 29-33.

Sichel, C., Garcia, C., Andre, K. (2011) Feasibility studies: UV/chlorine advanced oxidation treatment for the removal of emerging contaminants. Water Res. 45(19), 6371-6380.

Snyder, S.A., Wert, E.C., Lei, H., Westerhoff, P., Yoon, Y. (2007) Removal of EDCs and pharmaceuticals in drinking and reuse treatment processes, AWWA Research Foundation.

Soufan, M., Deborde, M., Delmont, A., Legube, B. (2013) Aqueous chlorination of carbamazepine: Kinetic study and transformation product identification. Water Res. 47(14), 5076-5087.

Sun, P., Lee, W.N., Zhang, R., Huang, C.H. (2016) Degradation of DEET and caffeine under UV/chlorine and simulated sunlight/chlorine conditions. Environ. Sci. Technol. 50 (24), 13265-13273

Vogna, D., Marotta, R., Andreozzi, R., Napolitano, A., d'Ischia, M. (2004) Kinetic and chemical assessment of the $\mathrm{UV} / \mathrm{H}_{2} \mathrm{O}_{2}$ treatment of antiepileptic drug carbamazepine. Chemosphere 54(4), 497-505.

Wang, D., Bolton, J.R., Hofmann, R. (2012) Medium pressure UV combined with chlorine advanced oxidation for trichloroethylene destruction in a model water. Water Res. 46(15), 4677-4686.

Wang, W.L., Wu, Q.Y., Huang, N., Wang, T., Hu, H.Y. (2016) Synergistic effect between UV and chlorine (UV/chlorine) on the degradation of carbamazepine: Influence factors and radical species. Water Res. 98, 190-198.

Watts, M.J., Hofmann, R., Rosenfeldt, E.J. (2012) Low-pressure UV/Cl 2 for advanced oxidation of taste and odor. J. Am. Water Works Assoc. 104(1), 58-65.

Westerhoff, P., Chao, P., Mash, H. (2004) Reactivity of natural organic matter with aqueous chlorine and bromine. Water Res. 38(6), 1502-1513.

Wiegman, S., Termeer, J.A.G., Verheul, T., Kraak, M.H.S., Voogt, P.D., Laane, R.W.P.M. and Admiraal, W. (2002) UV absorbance dependent toxicity of acridine to the marine diatomphaeodactylum tricornutum. Environ. Sci. Technol. 36(5), 908-913.

Wu, Z., Fang, J., Xiang, Y., Shang, C., Li, X., Meng, F., Yang, X. (2016) Roles of 
reactive chlorine species in trimethoprim degradation in the UV/chlorine process: Kinetics and transformation pathways. Water Res. 104, 272-282.

Xiang, Y., Fang, J., Shang, C. (2016) Kinetics and pathways of ibuprofen degradation by the UV/chlorine advanced oxidation process. Water Res. 90, 301-308.

Yang, B., Kookana, R.S., Williams, M., Du, J., Hai, D., Kumar, A. (2016) Removal of carbamazepine in aqueous solutions through solar photolysis of free available chlorine. Water Res. 100, 413-420.

Zhang, X., Li, W., Blatchley, E., Wang, X., Ren, P. (2015) UV/chlorine process for ammonia removal and disinfection by-product reduction: Comparison with chlorination. Water Res. 68, 804-811. 
Table 1. The observed and exact masses of the molecular ions, relative mass errors, and the proposed elemental compositions of the identified TPs.

\begin{tabular}{|c|c|c|c|c|c|c|}
\hline TPs & $\begin{array}{c}\text { RT } \\
(\min )\end{array}$ & $\begin{array}{c}\text { Measured } \\
\mathbf{m} / \mathbf{z}\end{array}$ & $\begin{array}{l}\text { Theoreti } \\
\text { cal } \mathbf{m} / \mathbf{z}\end{array}$ & $\begin{array}{l}\text { Predicted } \\
\text { formula }\end{array}$ & Proposed structure & $\begin{array}{l}\text { Mass } \\
\text { error } \\
(\mathrm{ppm})\end{array}$ \\
\hline CBZ & 1.74 & 237.1023 & 237.1022 & $\mathrm{C}_{15} \mathrm{H}_{12} \mathrm{~N}_{2} \mathrm{O}$ & & 0.4 \\
\hline $\mathbf{P}_{252 a}$ & 1.19 & 253.0977 & 253.0972 & $\mathrm{C}_{15} \mathrm{H}_{12} \mathrm{~N}_{2} \mathrm{O}_{2}$ & & 0.3 \\
\hline $\mathbf{P}_{252 \mathrm{~b}}$ & 0.85 & 253.0974 & 253.0972 & $\mathrm{C}_{15} \mathrm{H}_{12} \mathrm{~N}_{2} \mathrm{O}_{2}$ & & 0.3 \\
\hline $\mathbf{P}_{270 \mathrm{a}}$ & 0.82 & 271.1083 & 271.1082 & $\mathrm{C}_{15} \mathrm{H}_{14} \mathrm{~N}_{2} \mathrm{O}_{3}$ & & 1.1 \\
\hline $\mathbf{P}_{270 b}$ & 2.91 & 271.1083 & 271.1082 & $\mathrm{C}_{15} \mathrm{H}_{14} \mathrm{~N}_{2} \mathrm{O}_{3}$ & & 1.1 \\
\hline
\end{tabular}


$\begin{array}{lllll}\mathbf{P}_{270 c} & 2.91 & 271.0638 & 271.0633 & \mathrm{C}_{15} \mathrm{H}_{11} \mathrm{ClN}_{2} \mathrm{O}\end{array}$

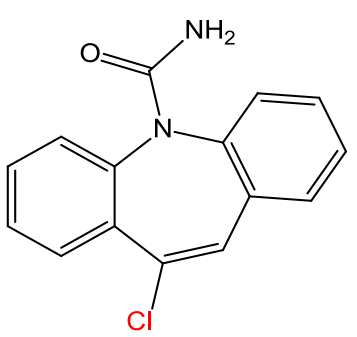

0.3

$\begin{array}{lllll}\mathbf{P}_{270 d} & 0.95 & 271.0633 & 271.0633 & \mathrm{C}_{15} \mathrm{H}_{11} \mathrm{ClN}_{2} \mathrm{O}\end{array}$

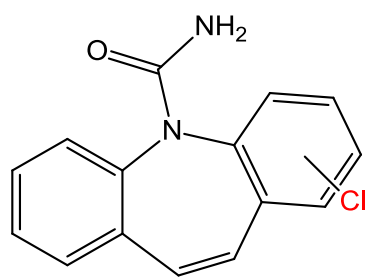

0.3<smiles>O=CN1c2ccccc2CC(O)c2ccccc21</smiles>

0.4

$\begin{array}{lllll}\mathbf{P}_{239} & 0.79 & 240.1025 & 240.1019 & \mathrm{C}_{15} \mathrm{H}_{13} \mathrm{NO}_{2}\end{array}$<smiles></smiles>

$\begin{array}{lllll}\mathbf{P}_{266 a} & 0.84 & 267.0765 & 267.0764 & \mathrm{C}_{15} \mathrm{H}_{10} \mathrm{~N}_{2} \mathrm{O}_{3}\end{array}$<smiles></smiles>

$\begin{array}{lllll}\mathbf{P}_{\text {266b }} & 1.36 & 267.0765 & 267.0764 & \mathrm{C}_{15} \mathrm{H}_{10} \mathrm{~N}_{2} \mathrm{O}_{3}\end{array}$<smiles>NC(=O)n1c2c(=O)ccc(=O)c=2ccc2ccccc21</smiles> 
$\begin{array}{lllll}\mathbf{P}_{235} & 1.2 & 236.0707 & 236.0706 & \mathrm{C}_{15} \mathrm{H}_{9} \mathrm{NO}_{2}\end{array}$<smiles>O=CC1c2ccccc2N2C(=O)c3cccc1c32</smiles>

$\begin{array}{lllll}\mathbf{P}_{209} & 1.2 & 210.0913 & 210.0913 & \mathrm{C}_{14} \mathrm{H}_{11} \mathrm{NO}\end{array}$<smiles>O=CC1c2ccccc2Nc2ccccc21</smiles>

$\begin{array}{lllll}\mathbf{P}_{225 a} & 4.09 & 226.0862 & 226.0863 & \mathrm{C}_{14} \mathrm{H}_{11} \mathrm{NO}_{2}\end{array}$<smiles>Cc1ccccc1C1C(O)N=C2C=CC=CC2C1C=O</smiles>

$\begin{array}{lllll}\mathbf{P}_{\text {225b }} & 0.81 & 226.0862 & 226.0863 & \mathrm{C}_{14} \mathrm{H}_{11} \mathrm{NO}_{2}\end{array}$<smiles>Cc1ccccc1C1c2ccccc2Nc2ccccc21</smiles>

$\begin{array}{lllll}\mathbf{P}_{259} & 0.95 & 260.0479 & 260.0473 & \mathrm{C}_{14} \mathrm{H}_{10} \mathrm{ClNO}_{2}\end{array}$<smiles>O=CC1c2ccccc2Nc2ccccc21</smiles><smiles>O=Cc1c2ccccc2nc2ccccc12</smiles> 
$\begin{array}{lllll}\mathbf{P}_{223} & 2.37 & 224.0706 & 224.0706 & \mathrm{C}_{14} \mathrm{H}_{9} \mathrm{NO}_{2}\end{array}$<smiles>O=Cn1c2ccccc2c(=O)c2ccccc21</smiles>

0.3

$\begin{array}{lllll}\mathbf{P}_{195 a} & 1.55 & 196.0756 & 196.0757 & \mathrm{C}_{13} \mathrm{H}_{9} \mathrm{NO}\end{array}$<smiles>O=c1c2ccccc2[nH]c2ccccc12</smiles><smiles>O=C1C2=CC=CCC2=Nc2ccccc21</smiles>

$\begin{array}{lllll}\mathbf{P}_{\text {195b }} & 2.38 & 196.0754 & 196.0757 & \mathrm{C}_{13} \mathrm{H}_{9} \mathrm{NO}\end{array}$<smiles>O=c1c2ccccc2[nH]c2cccc(O)c12</smiles>

$\begin{array}{lllll}\mathbf{P}_{211} & 1.04 & 212.0706 & 212.0706 & \mathrm{C}_{13} \mathrm{H}_{9} \mathrm{NO}_{2}\end{array}$<smiles>O=C1CC=Cc2c1c(=O)c1ccccc1n2Cl</smiles>

$\begin{array}{lllll}\mathbf{P}_{\text {229a }} & 3.01 & 230.0365 & 230.0367 & \mathrm{C}_{13} \mathrm{H}_{8} \mathrm{ClNO}\end{array}$<smiles></smiles> 


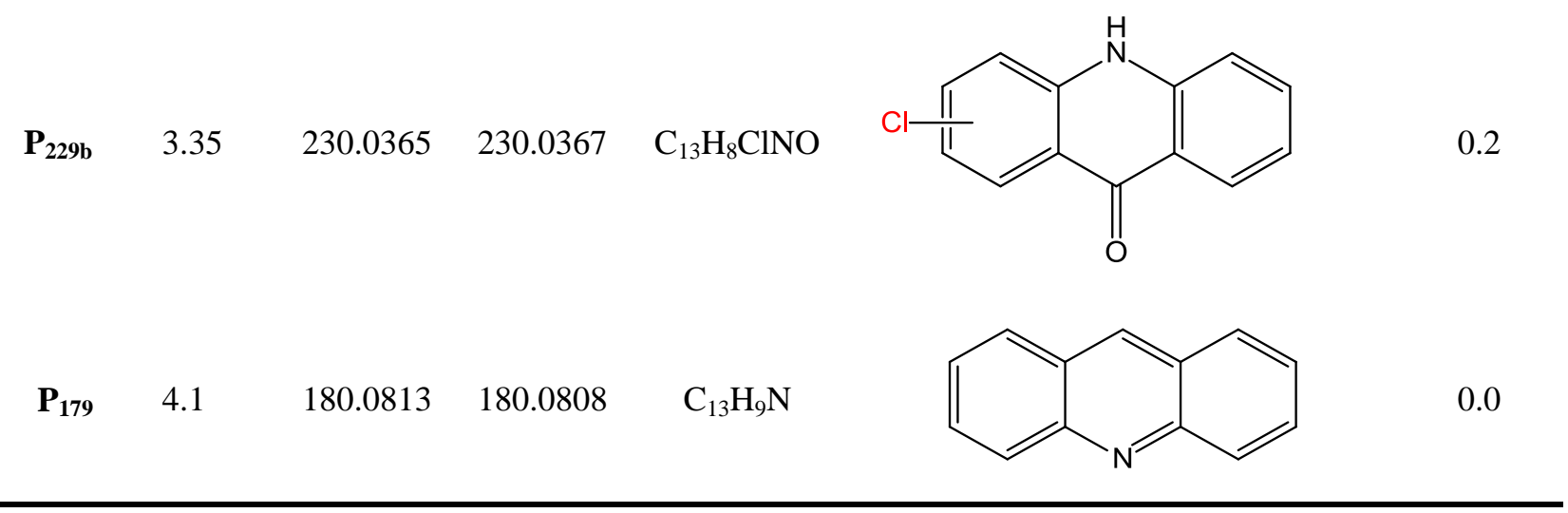


Table 2. Kinetic constants for the transformation of CBZ and the formation and decay of TPs I and IV.

\begin{tabular}{lllllll}
\hline & & CBZ & \multicolumn{2}{c}{ I: CBZ-EP } & \multicolumn{2}{c}{ IV: ACIN } \\
\hline & values & $\begin{array}{l}\mathrm{k}_{\text {obs }} \\
\left(\times 10^{-3} \mathrm{~s}^{-1}\right)\end{array}$ & $\begin{array}{l}\mathrm{k}_{\text {formation }} \\
\left(\times 10^{-3} \mathrm{~s}^{-1}\right)\end{array}$ & $\begin{array}{l}\mathrm{k}_{\text {decay }} \\
\left(\times 10^{-3} \mathrm{~s}^{-1}\right)\end{array}$ & $\begin{array}{l}\mathrm{k}_{\text {formation }} \\
\left(\times 10^{-3} \mathrm{~s}^{-1}\right)\end{array}$ & $\begin{array}{l}\mathrm{k}_{\text {decay }} \\
\left(\times 10^{-3} \mathrm{~s}^{-1}\right)\end{array}$ \\
\hline $\mathrm{Cl}_{2}(\mathrm{mg} / \mathrm{L})$ & 5 & 5.2 & 1.1 & 2.4 & 0.043 & 1.7 \\
& 10 & 8.2 & 2.1 & 2.1 & 0.049 & 1.8 \\
& 15 & 9.8 & 3.0 & 2.3 & 0.048 & 1.9 \\
& 20 & 13.4 & 4.3 & 2.6 & 0.052 & 1.9 \\
$\mathrm{pH}$ & 5 & 8.6 & 0.24 & 16.5 & 0.072 & 14.8 \\
& 6 & 6.2 & 0.43 & 7.6 & 0.064 & 7.2 \\
& 7 & 5.2 & 1.1 & 2.4 & 0.043 & 1.7 \\
& 9 & 3.1 & 0.54 & 1.4 & 0.034 & 1.2 \\
\multirow{2}{*}{ NOM (mg/L) } & 5 & 2.0 & 0.35 & 1.8 & & \\
& 10 & 1.2 & 0.14 & 2.5 & & \\
\hline
\end{tabular}




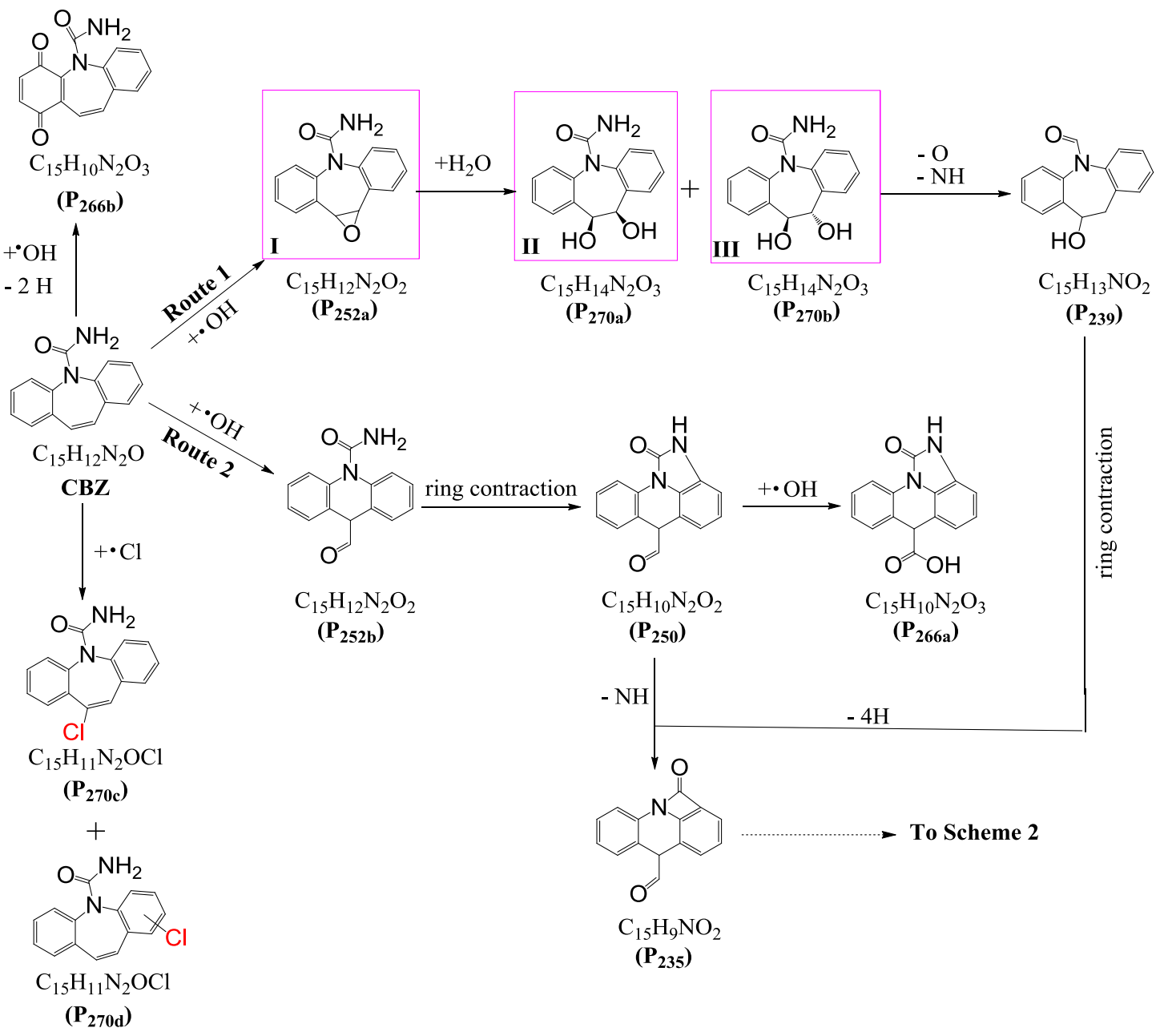

Scheme 1. Proposed CBZ transformation pathways in UV/chlorine treatment: Part I..

The commercial standards I, II and III are marked with color box. 

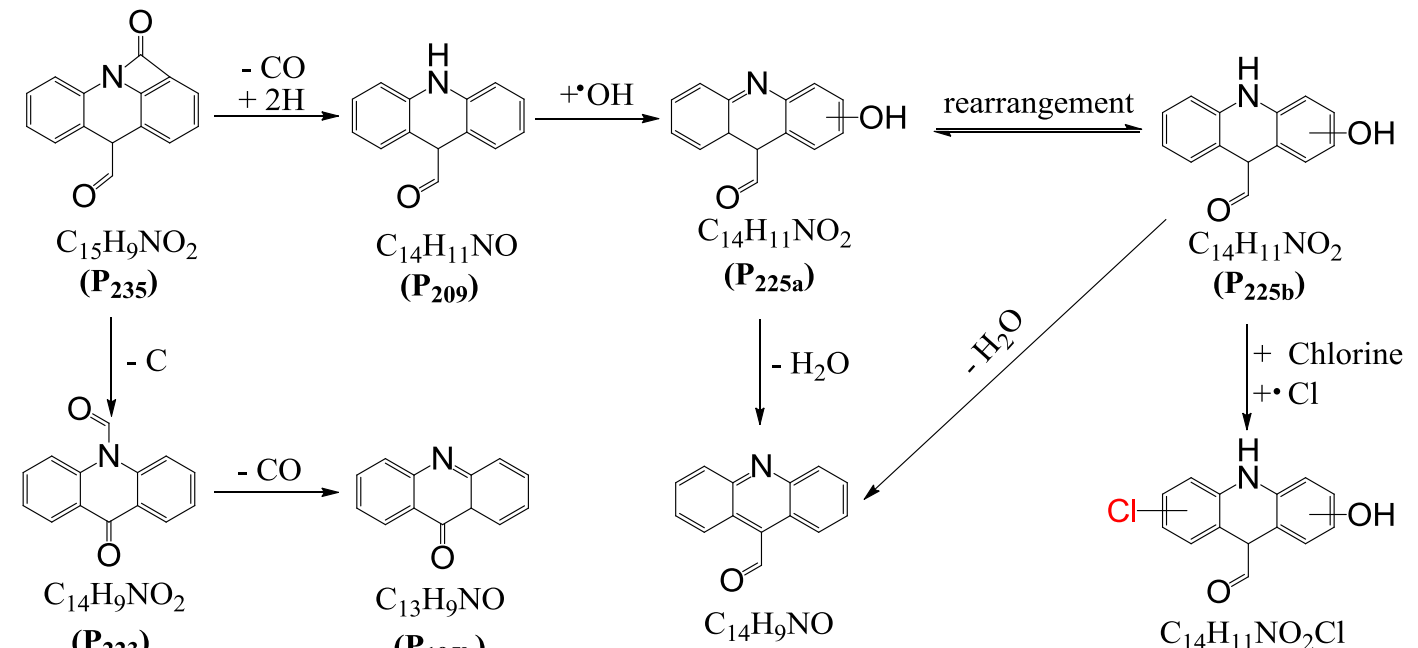

(223)<smiles>CC(C)(C)O</smiles>

$$
\text { (P } \mathbf{P}_{\text {195b) }}
$$

$$
\mathrm{C}_{14} \mathrm{H}_{9} \mathrm{NO}
$$

( $\left.\mathbf{P}_{207}\right)$

( $\mathbf{P}_{\text {259) }}$

$$
\mathrm{C}_{13} \mathrm{H}_{9} \mathrm{NO}_{2}
$$

$\left(\mathbf{P}_{\mathbf{2 1 1}}\right)$<smiles>O=c1c(Cl)c2cccc(Cl)n2c2ccccc12</smiles><smiles>C1CCCCC1</smiles>
rearrangement<smiles>O=c1c2ccccc2[nH]c2ccccc12</smiles>
$\mathrm{C}_{13} \mathrm{H}_{9} \mathrm{NOCl}$ ( $\left.\mathbf{P}_{229 a}\right)$ V $\mathrm{C}_{13} \mathrm{H}_{9} \mathrm{NO}$ ( $\left.P_{195 a}\right)$<smiles>C[13CH](C)Cl</smiles>
( $\mathbf{P}_{\text {229b) }}$<smiles></smiles>

$\mathrm{C}_{13} \mathrm{H}_{9} \mathrm{NO}_{2} \mathrm{Cl}$

( $\left.\mathbf{P}_{245}\right)$

Scheme 2. Proposed CBZ transformation pathways in UV/chlorine treatment: Part II The commercial standards IV and V are marked with color box. The compound in the dotted box is a proposed intermediate. 


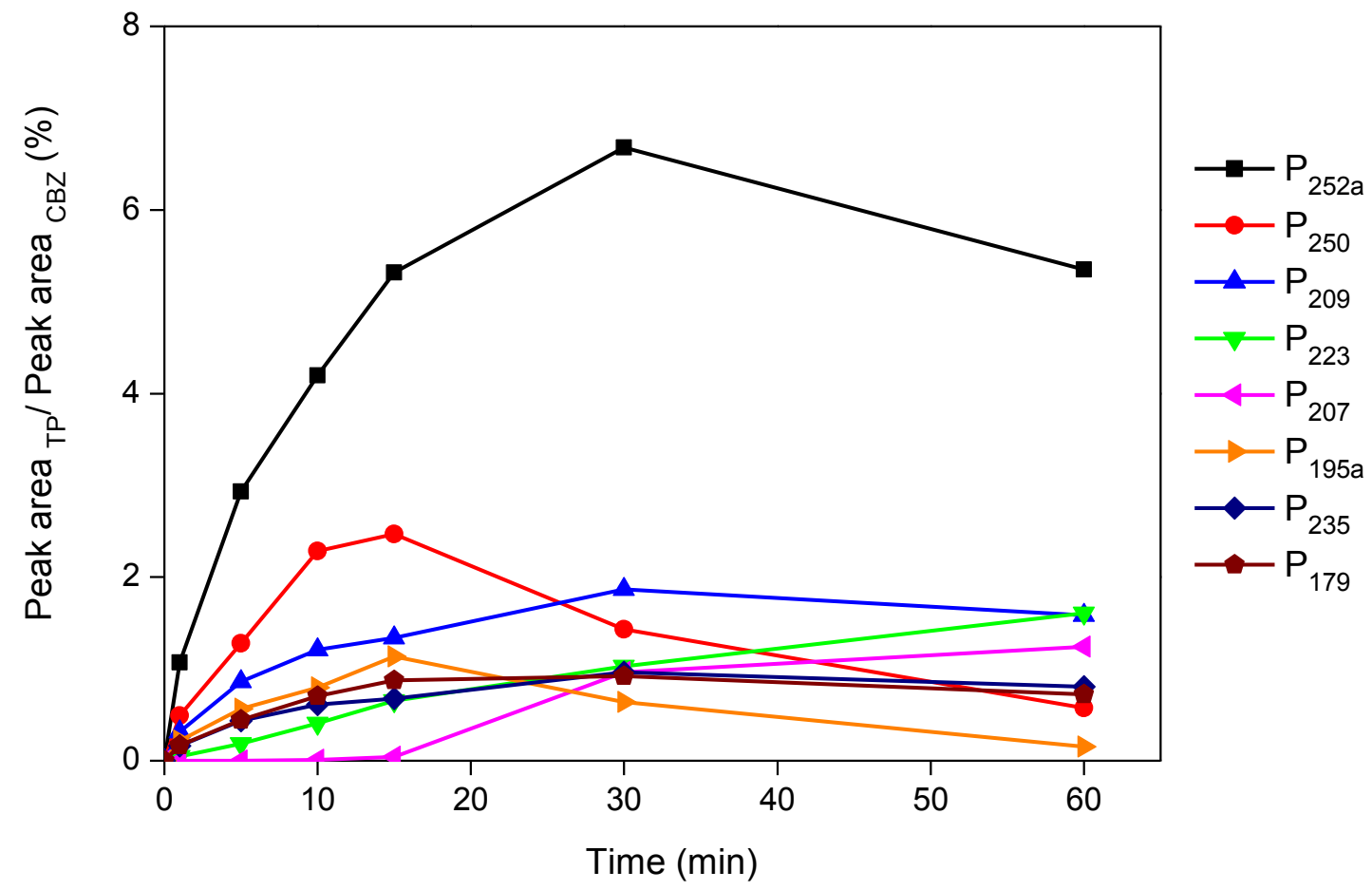

Figure 1. The profile of major TPs in UV/chlorine treatment of CBZ solutions.

Conditions: $\mathrm{CBZ}=63 \mu \mathrm{M}, \mathrm{Cl}_{2}=2.1 \mathrm{mM}, \mathrm{pH}=7.0$ 


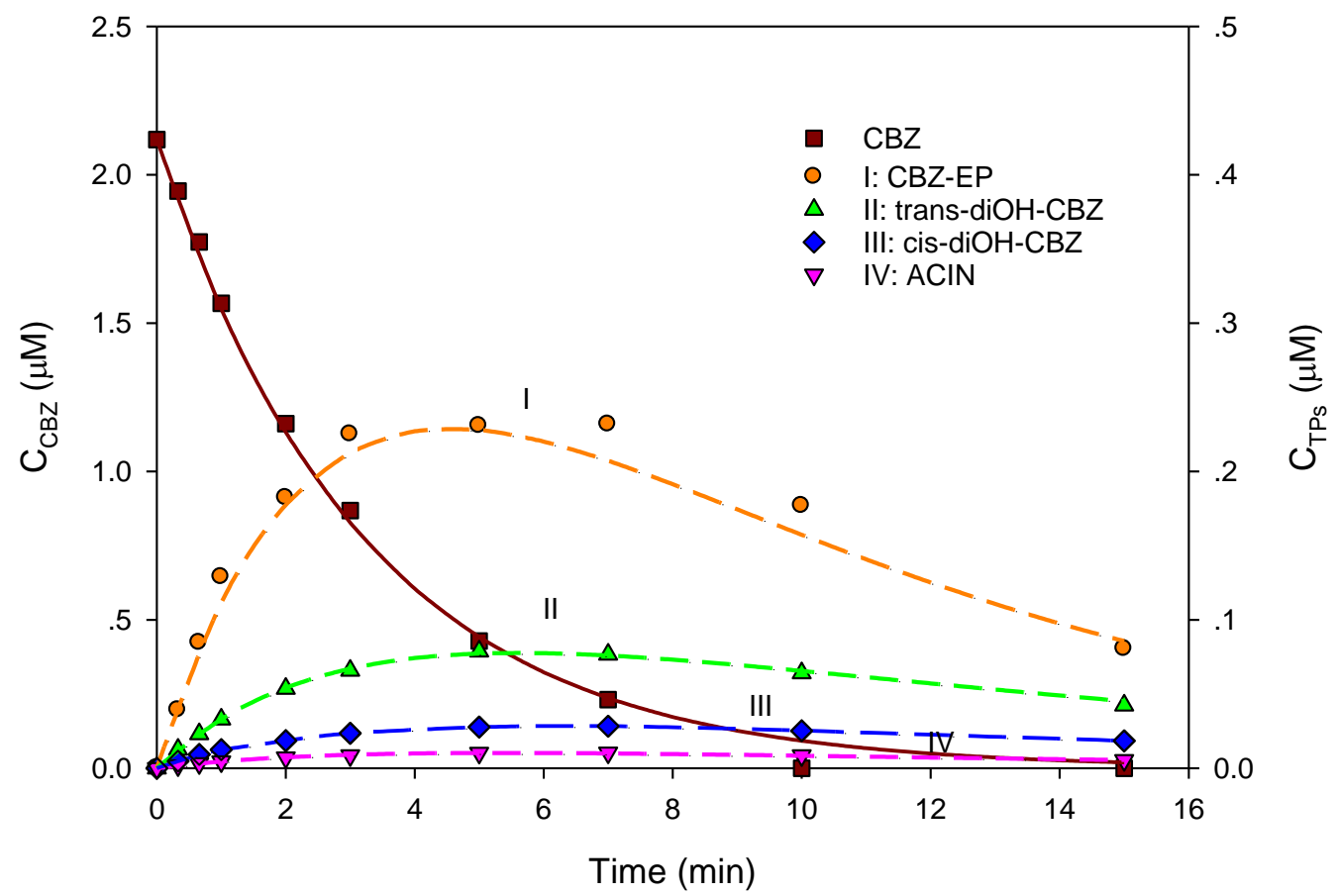

Figure 2. The degradation of CBZ and the evolution of TPs in UV/chlorine treatment.

Conditions: $\mathrm{CBZ}=2.1 \mu \mathrm{M}, \mathrm{pH}=7.0, \mathrm{Cl}_{2}=70 \mu \mathrm{M}$. 

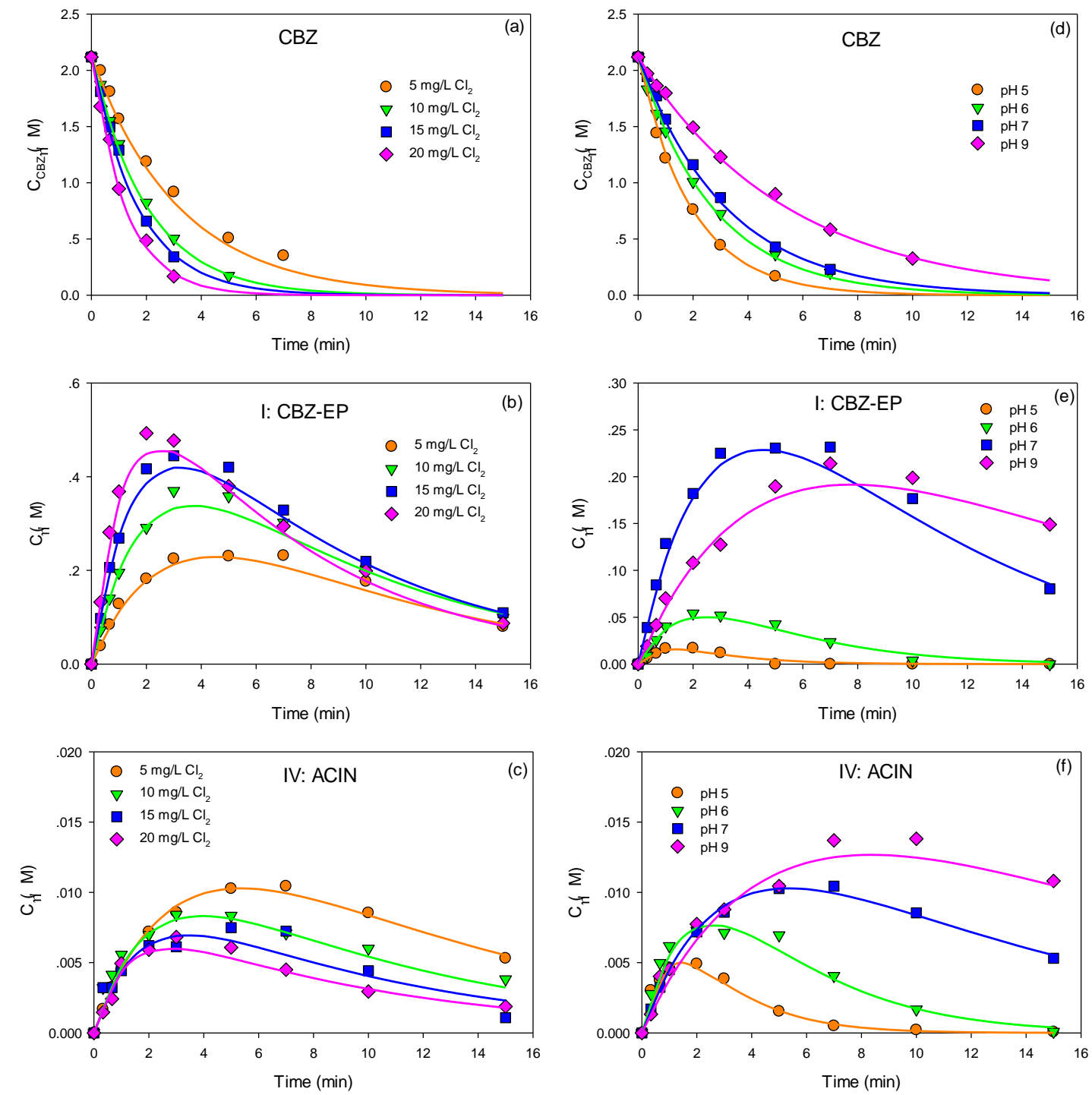

Figure 3. The degradation of CBZ $(2.1 \mu \mathrm{M})$ and the evolution of TP concentrations (products I and IV) during UV/chlorine treatment with various chlorine doses and pHs. 

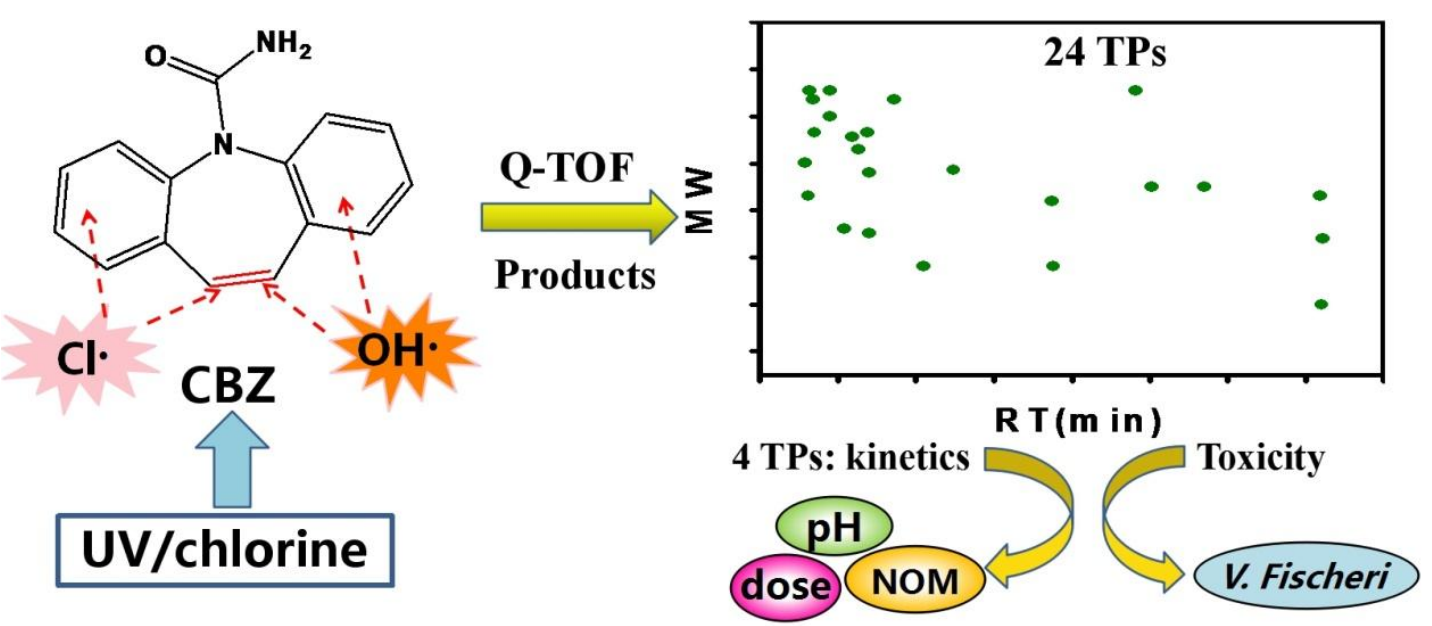